\title{
Pengembangan Soyghurt (Yoghurt Susu Kacang Kedelai) Sebagai Minuman Probiotik Tinggi Isoflavon
}

\section{Soyghurt (Soymilk Yoghurt) Probiotic Drink And High Isoflavone Development}

\author{
Naila Maziya Labiba*1, Avliya Quratul Marjan², Nanang Nasrullah ${ }^{3}$
}

\begin{abstract}
ABSTRAK
Latar Belakang: Peningkatan prevalensi penyakit tidak menular di Indonesia terjadi sebagai akibat adanya transisi pola konsumsi pangan, yaitu pola konsumsi pangan lokal menjadi pola konsumsi pangan cepat saji. Hal tersebut memicu terbentuknya radikal bebas di dalam tubuh yang dapat dicegah dengan mengonsumsi makanan atau kudapan tinggi antioksidan. Soyghurt atau yoghurt susu kacang kedelai merupakan minuman probiotik berbahan dasar susu nabati yang difermentasi dan diperuntukkan sebagai alternatif minuman tinggi antioksidan untuk mencegah terjadinya penyakit tidak menular. Jenis antioksidan utama dalam kacang kedelai adalah isoflavon yang bioavailabilitasnya akan meningkat selama proses fermentasi soyghurt.

Tujuan: Melakukan pengembangan produk soyghurt atau yoghurt susu kacang kedelai sebagai minuman probiotik tinggi isoflavon.

Metode: Jenis penelitian eksperimental dengan desain penelitian Rancangan Acak Lengkap menggunakan satu perlakuan yaitu penambahan rasio kacang kedelai sebesar $0 \%, 15 \%, 20 \%, 25 \%$. Kemudian dilakukan analisis sifat kimia (uji proksimat dan kadar isoflavon bebas), sifat fisik (viskositas dan nilai $\mathrm{pH}$ ), serta uji total bakteri asam laktat. Penentuan formula soyghurt terpilih dilakukan dengan metode perbandingan eksponensial.

Hasil: Formula soyghurt terpilih adalah soyghurt formula ketiga dengan rasio penambahan kacang kedelai sebesar $25 \%$ dengan kadar air $(81,74 \%)$, kadar abu $(0,49 \%)$, kadar protein $(5,98 \%)$, kadar lemak $(11,61 \%)$, kadar karbohidrat $(0,35 \%)$, kadar genistein $(250,46 \mu \mathrm{g} / \mathrm{g})$, kadar daidzein $(173,02 \mu \mathrm{g} / \mathrm{g})$, viskositas $(7111,4 \mathrm{cPoice})$, tingkat derajat keasaman $(4,63)$, dan total $\operatorname{BAL}\left(3,7 \times 10^{7} \mathrm{koloni} / \mathrm{ml}\right)$.

Kesimpulan: Soyghurt memiliki total bakteri asam laktat yang sesuai dengan standar nasional indonesia dan telah memenuhi klaim tinggi isoflavon berdasarkan acuan label gizi.
\end{abstract}

Kata kunci: isoflavon, kacang kedelai, probiotik, yoghurt

\section{ABSTRACT}

Background: Increased prevalence of non-communicable diseases in Indonesia occurs as the result of dietary transition, which is traditional dietary habit into fast-food dietary habit. Thus, triggers the formation of free radicals in human body which can be prevented by consumption of high antioxidant food. Soyghurt or soymilk yoghurt was a probiotic drink made of fermented soybean as an alternative drink with high antioxidant to prevent non-communicable diseases. Soybean was a major source of isoflavone as antioxidant and the bioavailability of isoflavone can be increased by fermentation in soyghurt.

Objectives: To developed high isoflavone soyghurt or soymilk yoghurt as probiotic drink.

Methods: This study used experimental method by used completely randomized design with added ratio of soybean were $0 \%$, 15\%, 20\%, 25\%. Soyghurt was analyzed by chemical properties (proximate analysis and free isoflavone content), physical properties (viscosity and $\mathrm{pH}$ ), also total lactic acid bacteria. Formula selection based on exponential comparison method. Results: The selected formula of soyghurt was the third formula which added by $25 \%$ ratio of soybean with water content $(81,74 \%)$, ash content $(0,49 \%)$, protein content $(5,98 \%)$, fat content $(11,61 \%)$, carbohydrate content $(0,35 \%)$, genistein content $(250,46 \mu \mathrm{g} / \mathrm{g})$, daidzein content $(173,02 \mu \mathrm{g} / \mathrm{g})$, viscosity $(7111,4 \mathrm{cPoice}), \mathrm{pH}(4,63)$, and total $\mathrm{LAB}\left(3,7 \times 10^{7}\right.$ coloni/m/).

Conclusions: Soyghurt had compatible total lactic acid bacteria with total starter bacteria in indonesian national standards of yoghurt and fulfilled claim of high isoflavone based on calculation of nutritional label reference.

Keywords: isoflavone, probiotics, soybean, yoghurt

\author{
*Koresponden: \\ Naila Maziya Labiba \\ Email: naila maziya@yahoo.co.id \\ 1,2,3 Program studi S-1 Ilmu Gizi, Universitas Pembangunan Nasional “VETERAN” Jakarta, Indonesia
}




\section{PENDAHULUAN}

Kejadian Penyakit Tidak Menular (PTM) tahun 2018 mengalami peningkatan sebesar 0,5\% hingga 8,3\% dibandingkan dengan kejadian PTM pada tahun $2013^{1}$. Salah satu penyebab dari peningkatan kejadian PTM adalah diet atau pola makan tidak sehat sebagai akibat dari terjadinya transisi pola konsumsi pangan, yaitu pola konsumsi pangan lokal menjadi pola konsumsi pangan cepat saji. Hal ini dibuktikan oleh data yang menunjukkan bahwa $36,8 \%$ penduduk Indonesia mengonsumsi makanan siap saji dengan frekuensi 2-3 kali dalam seminggu ${ }^{2}$. Umumnya makanan cepat saji memiliki komposisi gula, lemak, garam, dan energi tinggi. Berdasarkan data konsumsi pangan Indonesia, diketahui bahwa rata-rata penduduk Indonesia mengonsumsi gula $(4,8 \%)$, lemak $(26,5 \%)$, dan natrium $(52,7 \%)$ yang melebihi kebutuhan harian ${ }^{3}$.

Konsumsi makanan tinggi lemak dapat meningkatkan kadar serum Low Density Lipopotein (LDL), sehingga menyebabkan oksidasi serum LDL yang akan membentuk senyawa radikal bebas ${ }^{4}$. Radikal bebas adalah molekul tidak stabil yang dapat berinteraksi dengan senyawa lain secara cepat dan bersifat destruktif. Sifat inilah yang menyebabkan radikal bebas mampu merusak struktur sel tubuh dan menyebabkan berbagai jenis penyakit, terutama PTM. Untuk mencegah terjadinya proses oksidasi lemak dan melindungi sel dari kerusakan yang ditimbulkan oleh radikal bebas dapat dilakukan dengan mengonsumsi pangan tinggi antioksidan ${ }^{5}$.

Komponen dalam pangan nabati yang berperan sebagai antioksidan disebut dengan fitokimia. Salah satu jenis fitokimia adalah isoflavon yang berperan sebagai antioksidan guna melemahkan reaktivitas radikal bebas, mengurangi kadar LDL, serta meningkatkan aktivitas dan ekspresi dari enzim antioksidan ${ }^{6}$. Isoflavon banyak terdapat pada kacang-kacangan terutama kacang kedelai. Sebanyak $99 \%$ isoflavon pada kacang kedelai terdapat dalam bentuk glikosida yang terdiri dari $64 \%$ genistin, $23 \%$ daidzin, dan $13 \%$ glistin. Senyawa isoflavon glikosida dapat diubah menjadi senyawa aglikon melalui proses fermentasi dengan bantuan bakteri tertentu ${ }^{7}$. Senyawa aglikon ini memiliki bioavailabilitas yang lebih tinggi dibandingkan dengan glikosida, sehingga dapat dikatakan bahwa proses fermentasi akan meningkatkan bioavailabilitas isoflavon pada produk pangan olahan berbahan dasar kacang kedelai.

Salah satu produk pangan yang diolah secara fermentasi adalah yoghurt. Apabila dilihat dari komposisinya, yoghurt dapat dikategorikan sebagai pangan fungsional yaitu makanan yang bermanfaat untuk kesehatan manusia karena adanya penambahan zat selain zat gizi ${ }^{8}$. Zat selain zat gizi yang terdapat pada produk yoghurt adalah probiotik yaitu mikroorganisme hidup dalam pangan yang dapat menguntungkan inangnya dengan cara meningkatkan kinerja dari sistem mukosal dan sistem imun, sehingga dapat meningkatkan keseimbangan penyerapan zat gizi dan jumlah mikroba dalam usus. Pada umumnya yoghurt menggunakan bahan dasar susu hewani yaitu susu sapi, sedangkan yoghurt berbahan dasar susu nabati belum banyak dikenal di Indonesia ${ }^{9}$. Oleh karena itu, diperlukan adanya pengembangan produk yoghurt berbahan dasar susu nabati seperti kacang kedelai. Atas dasar pemikiran tersebut, penulis tertarik untuk melakukan pengembangan produk soyghurt (yoghurt susu kacang kedelai) sebagai minuman probiotik tinggi isoflavon. Produk soyghurt diharapkan dapat menjadi salah satu alternatif minuman kudapan dengan kandungan probiotik dan tinggi isoflavon sebagai komponen yang mampu meredam aktivitas radikal bebas dalam tubuh. Sehingga diharapkan dapat mencegah kejadian PTM di Indonesia.

\section{METODE}

Penelitian ini menggunakan desain studi penelitian eksperimental dengan Rancangan Acak Lengkap (RAL). Penelitian ini menggunakan prinsip penambahan rasio kacang kedelai tiap formula soyghurt (yoghurt susu kacang kedelai) untuk memperoleh klaim tinggi isoflavon berdasarkan perhitungan menggunakan Acuan Label Gizi (ALG). Suatu produk pangan dikatakan tinggi protein apabila mengandung 35\% ALG protein/100 gram bahan makanan ${ }^{10}$. Nilai ALG protein adalah 60 gram/100 gram bahan makanan ${ }^{11}$. Dari perhitungan tersebut dapat ditentukan berat kacang kedelai minimum sebagai formula awal (FO) sebesar 52 gram. Adapun estimasi kandungan isoflavon total dalam F0 diperkirakan sebesar 73,5 mg. Rerata persentase genistein dan daidzein sebelum fermentasi dalam isoflavon total adalah $0,061 \%$ dan $0,096 \%$ yang kemudian kadarnya akan meningkat sebesar $50 \%$ setelah fermentasi ${ }^{12,13}$. Berdasarkan perhitungan tersebut maka soyghurt dibuat dalam empat formula dengan penambahan rasio kacang kedelai sebesar $0 \%, 15 \%, 20 \%$, dan $25 \%$. Formulasi soyghurt disajikan pada tabel 1 .

Tabel 1. Formulasi Soyghurt

\begin{tabular}{lcccc}
\hline \multirow{2}{*}{ Bahan } & \multicolumn{4}{c}{ Perlakuan } \\
\cline { 2 - 5 } & F0 & F1 & F2 & F3 \\
\hline Kacang & 52 & 60 & 62 & 65 \\
Kedelai (g) & 3 & 3 & 3 & 3 \\
$\begin{array}{l}\text { Gula Pasir (g) } \\
\text { Bubuk Susu }\end{array}$ & 3 & 3 & 3 & 3 \\
Skim (g) & & & & \\
Bakteri & 1 & 1 & 1 & 1 \\
Starter (g) & 210 & 210 & 210 & 210 \\
Air (g) & & & & \\
\hline
\end{tabular}

Proses pembuatan soyghurt dibagi menjadi dua tahapan utama, yaitu pembuatan susu kacang kedelai dan pembuatan soyghurt: Tahapan pembuatan susu kacang kedelai adalah menyortir kacang kedelai dan mencuci. Kemudian, merendam kacang kedelai dengan air (1:3) selama 12 jam, lalu ditiriskan. Setelah itu, menerendam kacang kedelai dengan air dan $\mathrm{NaHCO}_{3}$, 0,5\% selama 30 menit, lalu bilas dengan air mengalir. Selanjutnya memisahkan kacang kedelai dengan kulit ari. 
Kemudian, memblender kacang kedelai dengan air $\left(85^{\circ} \mathrm{C}\right)$ selama 10 menit, setelah itu menyaring sari kacang kedelai dengan kain blacu. Setelah itu, mencampur sari kacang kedelai dengan gula pasir dan bubuk susu skim. Kemudian, memanaskan susu kacang kedelai hingga bersuhu $80^{\circ} \mathrm{C}$. Terakhir, mendinginkan susu kacang kedelai hingga bersuhu $42^{\circ} \mathrm{C}$. Tahapan pembuatan soyghurt adalah membuat kultur bakteri starter dengan cara menambahkan bakteri starter ke dalam $100-200 \mathrm{ml}$ susu kacang kedelai. Lalu, menginokulasikan susu kacang kedelai dengan kultur bakteri starter. Kemudian, menginkubasi soyghurt ke dalam inkubator sederhana selama 18 jam dengan suhu $35-37^{\circ} \mathrm{C}$. Terakhir, mendinginkan soyghurt di dalam kulkas dengan suhu $4^{\circ} \mathrm{C}$ untuk menghentikan proses fermentasi.

Penelitian ini dilakukan di di Laboratorium Teknologi Pangan, Fakultas Ilmu Kesehatan, Universitas Pembangunan Nasional "Veteran" Jakarta. Analisis sifat kimia (uji proksimat dan kadar isoflavon bebas) dan uji total BAL (Bakteri Asam Laktat) dilakukan di Laboratorium Terpadu Institut Pertanian Bogor. Analisis sifat fisik (viskositas dan nilai pH) dilakukan di Balai Besar Penelitian dan Pengembangan Pascapanen Bogor. Seluruh formula soyghurt dilakukan analisis sifat kimia, sifat fisik, dan total BAL. Kemudian, hasil analisis sifat kimia, fisik, dan total BAL dianalisis secara deskriptif. Setelah itu, dilakukan penentuan formula soyghurt terpilih dengan Metode Perbandingan Eksponensial (MPE), yaitu metode yang dilakukan dengan cara pembobotan pada hasil analisis sifat kimia, sifat fisik, serta total BAL yang kemudian ditentukan peringkatnya berdasarkan hasil skoring pada keempat formula soyghurt. Formula soyghurt terpilih akan ditentukan takaran saji dan informasi nilai gizi.

\section{HASIL DAN PEMBAHASAN}

Hasil analisis kimia, fisik, dan total BAL keempat formula soyghurt disajikan pada tabel 2 .

\section{Hasil Uji Proksimat \\ Kadar Air}

Berdasarkan hasil uji laboratorium pada tabel 2, kadar air soyghurt mengalami penurunan pada setiap formula. Kadar air tertinggi terdapat pada soyghurt FO dan kadar air terendah pada soyghurt F3. Hal ini dapat terjadi karena proporsi penambahan kacang kedelai yang ditambahkan semakin banyak pada tiap formula yang menyebabkan peningkatan kemampuan pengikatan air (imbibisi) kacang kedelai dalam soyghurt. Selain itu, penurunan kadar air soyghurt dapat pula disebabkan oleh kadar protein soyghurt yang mengalami peningkatan pada tabel 2. Kadar protein dapat mempengaruhi kadar air soyghurt karena memiliki sifat hidrofilik atau kemampuan menyerap air. Hal ini terjadi karena adanya ikatan rantai polar pada protein, seperti karbonil, hidroksil, karboksil, dan sulfuhidril yang akan berikatan dengan hidrogen pada air ${ }^{14}$.

\section{Kadar Abu}

Berdasarkan hasil uji laboratorium pada tabel 2, kadar abu soyghurt mengalami peningkatan pada setiap formula. Kadar abu tertinggi terdapat pada soyghurt F3 dan kadar abu terendah pada soyghurt FO. Adapun menurut standar mutu yoghurt dalam SNI 01-2981-2009, kadar abu dalam yoghurt maksimal adalah $1 \%$, sehingga dapat dikatakan bahwa soyghurt telah memenuhi standar SNI. Fermentasi soyghurt akan meningkatkan kandungan mineral, terutama kalsium, magnesium, dan seng ${ }^{15}$. Hal ini terjadi karena enzim phytase yang dihasilkan L. casei akan memecah ikatan mineral pada asam fitat yang telah berinteraksi dengan mineral dan residu protein ${ }^{16}$.

\section{Kadar Protein}

Berdasarkan hasil uji laboratorium pada tabel 2, kadar protein soyghurt mengalami peningkatan pada setiap formula. Hal ini dapat terjadi karena pada setiap formula soyghurt terjadi penambahan proporsi kacang kedelai. Semakin banyak penambahan kacang kedelai, maka akan semakin meningkat pula kadar protein pada soyghurt.

Tabel 2. Hasil analisis soyghurt

\begin{tabular}{|c|c|c|c|c|c|}
\hline \multirow{2}{*}{ Parameter } & \multirow{2}{*}{$\begin{array}{c}\text { Standar Mutu SNI } \\
\text { Yoghurt }\end{array}$} & \multicolumn{4}{|c|}{ Hasil Analisis Sifat Kimia Soyghurt } \\
\hline & & Fo & F1 & F2 & F3 \\
\hline \multicolumn{6}{|l|}{ Uji Proksimat } \\
\hline Kadar Air (\%) & - & 84,84 & 84,66 & 83,38 & 81,74 \\
\hline Kadar Abu (\%) & Maks. 1,0 & 0,39 & 0,48 & 0,49 & 0,49 \\
\hline Kadar Protein (\%) & Min. 2,7 & 5,41 & 5,67 & 5,79 & 5,98 \\
\hline Kadar Lemak (\%) & Min. 3,0 & 7,39 & 8,13 & 9,62 & 11,61 \\
\hline Kadar Karbohidrat (\%) & - & 1,95 & 1,02 & 0,51 & 0,35 \\
\hline \multicolumn{6}{|l|}{ Uji Kadar Isoflavon Bebas } \\
\hline Genistein $(\mu \mathrm{g} / \mathrm{g})$ & - & 163,83 & 196,79 & 218,06 & 250,46 \\
\hline Daidzein $(\mu \mathrm{g} / \mathrm{g})$ & - & 117,41 & 141,25 & 145,14 & 173,02 \\
\hline \multicolumn{6}{|l|}{ Uji Sifat Fisik } \\
\hline Viskositas (cPoice) & - & 2025,0 & 2592,6 & 3372,2 & 7111,4 \\
\hline Nilai pH & - & 4,23 & 4,27 & 4,57 & 4,63 \\
\hline \multicolumn{6}{|c|}{ Uji Total Bakteri Asam Laktat } \\
\hline Total BAL (koloni/ml) & Min. $10^{7}$ & $1,6 \times 10^{8}$ & $4,8 \times 10^{7}$ & $4,2 \times 10^{7}$ & $3,7 \times 10^{7}$ \\
\hline
\end{tabular}


Adapun menurut standar mutu yoghurt dalam SNI 012981-2009, kadar protein dalam yoghurt minimal adalah $2,7 \%$, sehingga dapat dikatakan bahwa kadar protein soyghurt lebih tinggi dibandingkan dengan standar SNI. Proses fermentasi soyghurt akan mempengaruhi bioavailabilitas protein. Hal ini dapat terjadi karena adanya reaksi penguraian protein oleh L. bulgaricus yang mengubah protein menjadi peptida dan asam amino ${ }^{17}$.

\section{Kadar Lemak}

Berdasarkan hasil uji laboratorium pada tabel 2, kadar lemak soyghurt mengalami peningkatan pada setiap formula. Hal ini dapat terjadi karena adanya penambahan proporsi kacang kedelai pada formula soyghurt. Adapun menurut standar mutu yoghurt dalam SNI 01-2981-2009, kadar lemak dalam yoghurt berkisar antara $0,5-3,0 \%$, sehingga dapat dikatakan bahwa soyghurt memiliki kadar lemak lebih tinggi dibandingkan dengan standar SNI. Hal ini dapat terjadi karena akitivitas enzim lipase BAL cenderung lebih lemah jika substrat lemak yang terkandung dalam pangan adalah lemak rantai panjang ${ }^{18}$. Komposisi lemak utama dalam kacang kedelai adalah asam linoleat yang merupakan polyunsaturated essential fatty acid dengan rantai karbon sebanyak 18 yang disebut juga dengan asam lemak omega 6. Selanjutnya, BAL akan kesulitan untuk memecah ikatan pada lemak yang menyebabkan lemak pada soyghurt tidak dapat terhidrolisis, sehingga menyebabkan peningkatan kadar lemak soyghurt.

\section{Kadar Karbohidrat}

Berdasarkan hasil uji laboratorium pada tabel 2, kadar karbohidrat pada soyghurt cenderung menurun terhadap proporsi penambahan kacang kedelai. Hal ini dapat terjadi karena BAL akan memproduksi poliol dengan jumlah besar sehingga dapat mengurangi kadar karbohidrat atau gula dalam soyghurt ${ }^{19}$. Poliol merupakan gula alkohol yang aman digunakan, secara alami dapat dijumpai dalam buah-buahan berupa laktitol, maltitol, mannitol, xylitol, dan sorbitol, sedangkan poliol secara buatan dapat diperoleh melalui proses fermentasi monosakarida.

\section{Hasil Kadar Isoflavon Bebas (Genistein dan Daidzein)}

Isoflavon dalam kacang kedelai terdapat dalam empat bentuk, yaitu aglikon (genistein, daidzein, glisitein), glikosida (genistin, daidzin, glistin), asetilglikosida (asetil genistin, asetil daidzin, asetil glistin), dan malonilglikosida (malonil genistin, malonil daidzin, malonil glistin). Isoflavon aglikon merupakan bentuk isoflavon bebas dari hasil hidrolisis enzim $\beta$-glikosidase yang memiliki bioavailabilitas lebih tinggi dibandingkan dengan bentuk glikosidanya. Enzim $\beta$-glikosidase dihasilkan oleh bakteri dalam usus manusia dan juga bakteri asam laktat yang digunakan dalam proses fermentasi produk pangan ${ }^{20}$. Jenis isoflavon bebas utama yang dihasilkan dalam proses fermentasi adalah genistein dan daidzein. Hal ini dikarenakan jumlah kedua senyawa tersebut lebih banyak dibandingkan glistein ${ }^{21}$.
Berdasarkan hasil uji laboratorium pada tabel 2, kadar isoflavon bebas dalam soyghurt mengalami peningkatan pada setiap formula. Hal ini dapat terjadi karena adanya penambahan proporsi kacang kedelai pada formula soyghurt. Kadar genistein soyghurt mengalami peningkatan sebesar $72-77 \%$ pada tiap formula, adapun kadar daidzein soyghurt mengalami peningkatan sebesar $39-49 \%$ pada setiap formula. Hasil ini sesuai dengan penelitian Lee $(2018)^{22}$, peningkatan kadar genistein dan daidzein pada fermentasi susu kacang kedelai adalah masing-masing sebesar $73 \%$ dan $42 \%$.

\section{Hasil Analisis Sifat Fisik Viskositas}

Berdasarkan hasil uji laboratorium pada tabel 2, nilai viskositas pada soyghurt mengalami peningkatan pada setiap formula. Peningkatan nilai viskositas pada soyghurt terjadi karena proporsi penambahan kacang kedelai yang semakin meningkat dalam tiap formula soyghurt yang menyebabkan peningkatan total padatan dalam soyghurt. Selain itu terdapat faktor lain yang mempengaruhi viskositas soyghurt, yaitu kadar protein dan kadar lemak. Kadar protein akan mempengaruhi viskositas karena protein memiliki kemampuan untuk mengikat molekul air yang akan menyebabkan peningkatan nilai viskositas jika kadar protein dalam yoghurt semakin tinggi ${ }^{23}$. Adapun kadar lemak dalam soyghurt juga akan mempengaruhi kekuatan struktur gel yang terbentuk pada soyghurt sehingga peningkatan kadar lemak akan meningkatkan nilai viskositas pada soyghurt ${ }^{24}$. Hal ini sesuai dengan hasil analisis kadar protein dan kadar lemak soyghurt pada tabel 2 yang juga semakin meningkat pada setiap formula.

\section{Nilai pH}

Berdasarkan hasil uji laboratorium pada tabel 2, nilai $\mathrm{pH}$ soyghurt mengalami peningkatan pada setiap formula. Peningkatan nilai $\mathrm{pH}$ yang terjadi pada soyghurt dapat terjadi karena adanya peningkatan nilai viskositas serta penurunan total BAL pada setiap formula. Viskositas yang meningkat akan menghambat BAL dalam melakukan reaksi fermentasi, sehingga asam laktat yang dihasilkan pun akan menurun yang menyebabkan peningkatan nilai $\mathrm{pH}$ pada soyghurt ${ }^{25}$.

\section{Hasil Total BAL}

Berdasarkan hasil uji laboratorium pada tabel 2, total BAL soyghurt mengalami penurunan pada setiap formula, sehingga dapat diketahui bahwa proporsi penambahan kacang kedelai pada soyghurt akan berbanding terbalik dengan total BAL yang diperoleh pada hasil uji. Meskipun total BAL soyghurt mengalami penurunan, jumlah BAL pada setiap formula soyghurt masih memenuhi standar SNI soyghurt, yaitu sebesar $10^{7}$ koloni/ml. Penurunan total BAL soyghurt dalam penelitian ini dapat disebabkan oleh tiga hal, yaitu jenis karbohidrat pada kacang kedelai, tingkat viskositas soyghurt, dan kadar isoflavon bebas dalam soyghurt. Jenis karbohidrat utama dalam kacang kedelai adalah 
raffinosa dan stakiosa yang merupakan oligosakarida ${ }^{26}$. Untuk menghidrolisis komponen tersebut, diperlukan enzim $\alpha$-galaktosidase yang dihasilkan oleh $\mathrm{BAL}^{27}$. Namun, jenis BAL yang digunakan dalam penelitian ini diketahui memiliki tingkat reaktivitas enzim $\alpha$ galaktosidase rendah ${ }^{28}$. Tingkat viskositas soyghurt yang semakin tinggi akan menghambat pertumbuhan BAL. Hal ini disebabkan, viskositas yang tinggi menandakan adanya penurunan kadar air pada soyghurt. Adapun air berfungsi sebagai media pendukung pertumbuhan BAL, yakni membantu dalam proses difusi nutrisi yang diperlukan oleh $\mathrm{BAL}^{29}$. Isoflavon merupakan antioksidan yang dapat pula berperan sebagai antimikroba ${ }^{30}$, sehingga dapat mempengaruhi penurunan pertumbuhan BAL dalam soyghurt. Akan tetapi, sifat antimikroba pada isoflavon lebih spesifik untuk mencegah pertumbuhan mikroba patogen dalam tubuh, seperti E. coli, V. harveyi, dan Bacillus subtilis ${ }^{31}$

\section{Penentuan Formula Terpilih}

Penentuan formula terpilih dilakukan dengan melakukan pembobotan (dalam persentase) pada hasil analisis laboratorium soyghurt sesuai dengan derajat kepentingan atau aspek yang diunggulkan pada produk soyghurt dibandingkan dengan produk yoghurt komersial. Parameter yang dipertimbangkan dalam penentuan formula terpilih adalah kadar air (15\%), kadar protein (15\%), kadar genistein (20\%), kadar daidzein (20\%), nilai viskositas (5\%), nilai pH (5\%) dan total BAL (20\%). Selanjutnya dilakukan perkalian antara nilai bobot dengan ranking masing-masing parameter untuk memperoleh skor tiap parameter dalam masing-masing formula soyghurt. Kemudian skor pada setiap parameter dijumlahkan untuk menentukan ranking tiap formula. Berdasarkan uraian di atas dan perhitungan yang dilakukan pada setiap formula, maka formula soyghurt terpilih adalah formula ketiga (F3).

\section{Penentuan Takaran Saji dan Informasi Nilai Gizi Soyghurt}

Soyghurt F3 merupakan formula terbaik dalam penelitian ini, sehingga dalam penentuan takaran saji dan informasi nilai gizi soyghurt dilakukan pada soyghurt F3. Takaran saji soyghurt yang disarankan adalah $175 \mathrm{ml}$ dengan mempertimbangkan syarat klaim tinggi protein, yaitu sebesar 17,5\% ALG untuk memperoleh klaim tinggi isoflavon. Informasi nilai gizi soyghurt disajikan pada tabel 3. Saran penyajian soyghurt adalah sekali dalam sehari sebanyak $175 \mathrm{ml}$ yang diperuntukkan sebagai makanan selingan. Proporsi makanan selingan dalam sehari adalah dua kali, yakni pada pagi dan sore sebanyak masingmasing $10 \%$ dari kebutuhan harian yang mengacu pada ALG. Produk soyghurt telah memenuhi $10 \%$ ALG pada komposisi energi, lemak, dan protein, namun belum mencukupi $10 \%$ ALG karbohidrat. Untuk itu pada saat mengonsumsi soyghurt diperlukan makanan pendamping dengan kandungan karbohidrat cukup dan rendah lemak, seperti buah-buahan, yaitu apel, pisang, melon, dan mangga.
Tabel 3. Informasi Nilai Gizi soyghurt

\begin{tabular}{|c|c|c|}
\hline \multicolumn{3}{|c|}{ INFORMASI NILAI GIZI } \\
\hline $\begin{array}{l}\text { Takaran Saji/Serving } \\
\text { Size: } 175 \mathrm{ml}\end{array}$ & $\begin{array}{l}\text { Jumlah } \\
\text { kemas }\end{array}$ & sajian \\
\hline \multicolumn{3}{|c|}{ Jumlah Per Sajian } \\
\hline Energi Total & 227 kk & \\
\hline \multirow[t]{2}{*}{ Energi dari lemak } & $208 \mathrm{kk}$ & \\
\hline & & \%AKG* \\
\hline Lemak Total & $20 \mathrm{~g}$ & $57 \%$ \\
\hline Protein & $10 \mathrm{~g}$ & $18 \%$ \\
\hline Karbohidrat Total & $0,6 \mathrm{~g}$ & $0,3 \%$ \\
\hline \multicolumn{3}{|c|}{$\begin{array}{l}\text { *Persen AKG berdasarkan kebutuhan energi } 2150 \text { kkal. } \\
\text { Kebutuhan energi anda mungkin lebih tinggi atau lebih } \\
\text { rendah. }\end{array}$} \\
\hline
\end{tabular}

Mengandung $741 \mu \mathrm{g}$ isoflavon bebas per sajian

\section{KESIMPULAN}

Soyghurt (yoghurt susu kacang kedelai) dapat dikatakan sebagai minuman probiotik tinggi isoflavon. Hal ini disebabkan oleh total BAL soyghurt telah memenuhi standar jumlah bakteri starter pada SNI yohurt serta kadar isoflavon bebas soyghurt telah memenuhi syarat klaim tinggi isoflavon yang telah ditentukan, yaitu genistein $(67,2-84,0 \mu \mathrm{g} / \mathrm{g})$ dan daidzein $(105-132 \mu \mathrm{g} / \mathrm{g})$. Formula terpilih yang diperoleh dari hasil analisis uji ranking adalah soyghurt $\mathrm{F} 3$ dengan proporsi penambahan kacang kedelai $65 \mathrm{~g}$. Soyghurt dengan formula terpilih memiliki kadar air $(81,74 \%)$, kadar abu $(0,49 \%)$, kadar protein $(5,98 \%)$, kadar lemak $(11,61 \%)$, kadar karbohidrat $(0,35 \%)$, kadar genistein $(250,46 \mu \mathrm{g} / \mathrm{g})$, kadar daidzein $(173,02 \mu \mathrm{g} / \mathrm{g})$, viskositas (7111,4 cPoice), tingkat derajat keasaman $(4,63)$, dan total BAL $\left(3,7 \times 10^{7}\right.$ koloni $\left./ \mathrm{ml}\right)$. Takaran saji soyghurt formula terpilih adalah $175 \mathrm{ml}$ dengan komposisi nilai gizi meliputi energi 227 kkal, lemak total $20 \mathrm{~g}$, protein $10 \mathrm{~g}$, karbohidrat total $0,6 \mathrm{~g}$, dan isoflavon bebas $741 \mu \mathrm{g}$.

\section{ACKNOWLEDGEMENT}

Penulis mengucapkan terima kasih kepada seluruh Dosen Gizi Program Studi S1 IImu Gizi Universitas Pembangunan Nasional "VETERAN" Jakarta yang telah membantu dan memberikan dukungan dalam penelitian ini.

\section{REFERENS}

1. Indonesia, K. K. R. Hasil Utama RISKESDAS 2018. (2019).

2. Inc, S. Indonesia - Average Fast Food Consumption Per Week In 2016-2018. 1 (2019). Available at: https://www.statista.com/statistics/561273/ind onesia-average-fast-food-consumption-perweek/.

3. Lamid, A. Food Consumption Survey (FCS) Indonesia 2014. in 23 (Kementerian Kesehatan Republik Indonesia, 2016).

4. Kesh, S. B., Sarkar, D. \& Manna, K. High-Fat Diet- 
Induced Oxidative Stress and Its Impact on Metabolic Syndrome: A Review. Asian J Pharm Clin Res 9, 47-52 (2016).

5. Kumar, S. Free Radicals and Antioxidants: Human and Food System. Pelagia Res. Libr. Adv. Appl. Sci. Res. 2, 129-135 (2011).

6. Yoon, G. A. \& Park, S. Antioxidant Action of Soy Isoflavones on Oxidative Stress and Antioxidant Enzyme Activities in Exercised Rats. Nutr. Res. Pract. 8, 618-624 (2014).

7. Sussi, A. Isoflavon Kedelai dan Potensinya sebagai Penangkap Radikal Bebas. J. Teknol. Ind. dan Has. Pertan. 13, 126-136 (2008).

8. Kusumayanti, H., Triaji, R. \& Bagus, S. Pangan Fungsional Dari Tanaman Lokal Indonesia. Metana 12, 26-30 (2016).

9. Rumiyati, E. \& Nurhidayati, A. Biosuplemen of Synbiotic in Soyghurt as Imunostimulatory and Lowering Cholesterol Levels. in Seminar Nasional XI Pendidikan Biologi FKIP UNS 27-32 (2015).

10. Indonesia, B. P. O. dan M. R. Pengawasan Klaim Pada Label Dan Iklan Pangan Olahan. 1-56 (Badan Pengawas Obat dan Makanan Republik Indonesia, 2016).

11. Indonesia, B. P. O. dan M. Acuan Label Gizi Produk Pangan. Badan Pengawas Obat dan Makanan 53, 1689-1699 (Badan Pengawas Obat dan Makanan Republik Indonesia, 2005).

12. Mark Messina, C. N. \& A. H. W. Estimated Asian Adult Soy Protein and Isoflavone Intakes. Nutr. Cancer 5581, 37-41 (2009).

13. Nur, F. A. Uji Kandungan Senyawa Isoflavon Kalus Kedelai (Glycine max (L) Merr) pada Media B5 dengan Penambahan PEG (Polyethene Glycol) 6000. (Universitas Islam Negeri (UIN) Maulana Malik Ibrahim Malang, 2010).

14. Denta Elygio, Y., Mohamad Legowo, A., Ni, A. \& Al-Baarri, M. Karakteristik Curd Berbahan Dasar Ekstrak Kacang Hijau (Vigna radiata) dengan Whey Tahu Kedelai (Glycine max) Sebagai Bahan Penggumpal. J. Teknol. Has. Pertan. IX, 33-39 (2016).

15. Kumari, A., Angmo, K., Monika, S., Bhalla, T. C. Functional and technological application of probiotic L . casei PLA5 in fermented soymilk. Int. Food Res. J. 25, 2164-2172 (2018).

16. Nissar, J., Ahad, T., Naik, H. R. \& Hussain, S. Z. A review phytic acid: As antinutrient or nutraceutical. $1554 \sim$ J. Pharmacogn. Phytochem. 6, 1554-1560 (2017).

17. Suryana, I. G. Pengaruh penambahan jenis susu terhadap karakteristik yogurt kacang kedelai (soygurt) ilham gelar suryana. (Institut Pertanian Bogor, 2013).

18. Chandan, R. C. \& O’Rell, K. R. Principles of Yogurt Processing. Manuf. Yogurt Fermented Milks 195-
210 (2007). doi:10.1002/9780470277812.ch12

19. Sharma Ranjana, S. N. and H. S. Nutritional and quality attributes of fortified soy yogurt prepared by using probiotic food grade lactic acid bacteria. Indian J. Dairy Sci. 69, 441-461 (2016).

20. Gatchell, S. Isoflavone sources and bioavailability. Biological effects of phytoestrogens in the diet. (2016).

21. Zuhri, M. A. M. Pengaruh intervensi tahu kedelai hitam terhadap kontrol glikemik penderita diabetes melitus muhammad abdi manaf zuhri. (Institut Pertanian Bogor, 2015).

22. Lee, J. H. et al. Changes in conjugated linoleic acid and isoflavone contents from fermented soymilks using Lactobacillus plantarum P1201 and screening for their digestive enzyme inhibition and antioxidant properties. J. Funct. Foods 43, 17-28 (2018).

23. Bayu, K. et al. Analisis Total Padatan Terlarut, Keasaman, Kadar Lemak, dan Tingkat Viskositas pada Kefir Optima dengan Lama Fermentasi yang Berbeda Total Dissolved Solid, Acidity, Lipid, and Degree of Viscosity Analysis of Kefir Optima at Different Fermentation Duration. J. Teknol. Pangan 1, 33-38 (2017).

24. Yu, H. Y., Wang, L. \& McCarthy, K. L. Characterization of yogurts made with milk solids nonfat by rheological behavior and nuclear magnetic resonance spectroscopy. J. Food Drug Anal. 24, 804-812 (2016).

25. Lita Purnamasari, Purwadi, I. T. Kualitas Yoghurt Set Dengan Penambahan Berbagai Konsentrasi Pati Ubi Jalar (Ipomoea batatas L) Ikat Silang. 2, (2013)

26. O'Keefe, S., Bianchi, L. \& Sharman, J. Soybean nutrition. SM J. Nutr. Metab. 1, 1006 (2015).

27. Chen, M. \& Mustapha, A. Survival of freeze-dried microcapsules of $\alpha$-galactosidase producing probiotics in a soy bar matrix. Food Microbiol. 30, 68-73 (2012).

28. Zartl, B. et al. Fermentation of non-digestible raffinose family oligosaccharides and galactomannans by probiotics. Food Funct. 9, 1638-1646 (2018).

29. Douillard, F. P. \& de Vos, W. M. Functional genomics of lactic acid bacteria: From food to health. Microb. Cell Fact. 13, S8 (2014).

30. Albert Dhayakaran, R. P., Neethirajan, S., Xue, J. \& Shi, J. Characterization of antimicrobial efficacy of soy isoflavones against pathogenic biofilms. LWT - Food Sci. Technol. 63, 859-865 (2015).

31. Wang, Q., Wang, H. \& Xie, M. Antibacterial mechanism of soybean isoflavone on Staphylococcus aureus. Arch. Microbiol. 192, 893-898 (2010). 